\title{
EVALUATING THE LONG-TERM INFLUENCE OF ALTERNATIVE COMMERCIAL THINNING REGIMES AND HARVESTING SYSTEMS ON PROJECTED NET PRESENT VALUE OF PRECOMMERCIALLY THINNED SPRUCE-FIR STANDS IN NORTHERN MAINE
}

\begin{tabular}{|r|l|}
\hline Journal: & Canadian Journal of Forest Research \\
\hline Manuscript ID & cjfr-2016-0228.R2 \\
\hline Manuscript Type: & Article \\
\hline Date Submitted by the Author: & $24-$ Oct-2016 \\
\hline Complete List of Authors: & $\begin{array}{l}\text { Hiesl, Patrick; Clemson University, Department of Forestry and } \\
\text { Environmental Conservation } \\
\text { Crandall, Mindy; University of Maine, School of Forest Resources } \\
\text { Weiskittel, Aaron; University of Maine } \\
\text { Benjamin, Jeffery; University of Maine, School of Forest Resources } \\
\text { Wagner, Robert; University of Maine }\end{array}$ \\
\hline Keyword: & $\begin{array}{l}\text { Commercial thinning, New England, Net Present Value, Harvesting System, } \\
\text { Spruce/Fir }\end{array}$ \\
\hline
\end{tabular}

\section{SCHOLARONE \\ Manuscripts}


EVALUATING THE LONG-TERM INFLUENCE OF ALTERNATIVE COMMERCIAL THINNING REGIMES AND HARVESTING SYSTEMS ON PROJECTED NET PRESENT VALUE OF PRECOMMERCIALLY THINNED SPRUCE-FIR STANDS IN NORTHERN MAINE (1)

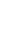

Patrick Hiesl $^{1 \text { a }}$, Mindy S. Crandall ${ }^{1}$, Aaron Weiskittel ${ }^{1}$, Jeffrey G. Benjamin ${ }^{1}$, and Robert G. Wagner ${ }^{1}$

${ }^{1}$ University of Maine, School of Forest Resources, 5755 Nutting Hall, Orono, ME 04469

Email addresses:

PH (phiesl@clemson.edu), MSC (ㅆindy.crandall@maine.edu), AW (aaron.weiskittel@maine.edu), JGB (jeffrey.g.benjamin@maine.edu), RGW (robert.wagner@maine.edu)

(1)

(1)

18

(1)

(1)

(3)

\author{
Corresponding Author: \\ Patrick Hiesl \\ Clemson University \\ Department of Forestry and Environmental Conservation \\ 261 Lehotsky Hall \\ Clemson, SC 29634 \\ Phone: 864-656-7293 \\ phiesl@clemson.edu
}

\footnotetext{
a Assistant Professor of Forest Operations, Clemson University, Department of Forestry and Environmental Conservation, 261 Lehotsky Hall, Clemson, SC 29634, Phone: (864) 656-7293, phiesl@clemson.edu 


\section{ABSTRACT}

Commercial thinning (CT) is an important silvicultural practice in the northeastern US.

26 Relatively little is known, however, about the interaction of harvest system and treatment

27 (removal intensity or timing of entry) on the overall profitability of CT. To address this question,

28 ten-year measurements from a controlled CT experiment across six sites in Maine were used to

29 project the long-term effect of removal intensity (33\% and $50 \%$ relative density reduction) and

30 timing of entry (no-delay, 5-year delay, 10-year delay) on: (1) maximum net present value

31 (NPV), (2) timing of maximum NPV, and (3) the effect of three harvesting systems (cut-to-

32 length, whole-tree, hybrid system) on maximum NPV. A regional growth and yield model was

33 used to project individual-tree growth and mortality into the future. Harvest costs for the

34 harvesting systems were estimated using regional cycle-time equations. No difference was

35 found in maximum NPV between the CT and non-CT areas, or the timing of CT entry. Stand

36 age at time of maximum NPV differed between delays but not between the two removal

37 intensities. Our results indicate that there is no economic benefit in delaying a CT nor removing

38 more volume at the time of thinning for the range of stand conditions evaluated.

40 Keywords: Commercial Thinning; New England; Net Present Value; Harvesting System;

41 Spruce/Fir

42

43 


\section{INTRODUCTION}

The management of forests for timber production generally includes a series of treatments aimed at improving stand growth and yield. Herbicide application, precommercial

47 thinning (PCT), and commercial thinning (CT) are often used to manage conifer forests in North

48 America and Europe (e.g. Hiesl et al. 2015; Bataineh et al. 2013; Zhang et al. 2009; Zeide

49 2001). The use of herbicides has been shown to reduce competition from early successional 50 vegetation and increase softwood stand growth (Wagner et al. 2006), whereas PCT is a 51 common and widely applied tool for density management (Nyland 2002; Smith 1986). PCT is

52 also applied to control species composition (Weiskittel et al. 2011), accelerate growth (Prévost 53 and Gauthier 2012), reduce time to merchantability (Pitt et al. 2013a; Pitt and Lanteigne 2008),

54 improve commercial operability, reduce harvesting and processing costs (Plamondon and Pitt 55 2013), and increase landowner stumpage revenues (Pitt et al. 2013a). A CT treatment is often 56 prescribed years after PCT to maintain or increase residual tree growth (Clune 2013; Reukema 57 and Bruce 1977) and decrease mortality (Pekol 2011; Mäkinen and Isomäki 2004a,b).

The benefits of CT on spruce-fir (Picea spp. / Abies balsamea (L.) Mill.) stand stability 59 and growth in Maine have been shown by Clune (2013), whose results indicate a positive 60 influence from early, light thinning on short-term growth and yield. Pelletier and Pitt (2008) 61 showed an increase in growth and yield as a response to CT in stands dominated by balsam fir 62 in Canada, and noted a shorter time to grow merchantable trees. However, the long-term effects 63 of combined PCT and CT in spruce-fir stands is limited, with the exception of the Green River 64 Study in northwestern New Brunswick, Canada (Pitt and Lanteigne 2008; Baskerville 1959), the 65 Austin Pond Study in west-central Maine, USA (Newton et al. 1992a,b), and the Commercial 66 Thinning Research Network (CTRN) across the state of Maine (Wagner et al. 2001; Wagner 67 and Seymour 2000). 
Spruce and fir are the most harvested timber species in Maine (Maine Forest Service 2014) and contribute significantly to the state's annual 8 billion dollar forest-based economy 70 (Maine Forest Products Council 2013). Herbicide application, PCT, and CT are common tools

71 used in the management of spruce-fir stands, however, long-term results of tree growth and 72 studies of the financial returns of these treatments in Maine are limited. Hiesl et al. (2015) 73 investigated the differences in harvest cost and profits of three different CT intensities in a 74 spruce-fir stand in central Maine. Their results indicated that there was no difference in unit cost 75 between the different removal intensities. They further reported no difference in unit profit 76 between treatment areas with and without a previous PCT treatment. However, two different 77 harvesting systems were used in their study, thus results might not be easily comparable.

78 Bataineh et al. (2013) also investigated the long-term financial response of spruce-fir stands in 79 Maine to herbicide and PCT treatments and found that at a $2 \%$ interest rate, herbicide and PCT 80 treated stands resulted in up to $140 \%$ higher net present value (NPV) than only herbicide 81 treated stands approximately 60 years post clearcut. Their study, however, did not include 82 subsequent CT treatments. Using a 4\% discount rate, Pitt et al. (2013b) analyzed the NPV of 83 vegetation management and PCT in fir dominated stands in New Brunswick, Canada, and found 84 that both treatments offered a similar NPV at a stand age that maximizes sawlog production. 85 Finally, Saunders et al. (2008) simulated stand growth of spruce-fir stands in the Northeastern 86 US and Eastern Canada and found that the NPV of CT stands culminated earlier and at a 87 higher value than unthinned stands. They also found that early CT added approximately $\$ 370$ 88 United States Dollar (USD)/ha (\$150 USD/ac) to the maximum NPV that could be achieved 89 without CT on the lowest quality sites.

Forest managers in Maine are often faced with the challenge of managing forestland that 91 was inherited by company acquisitions or other ownership changes. Such forestland often 
92 already received a herbicide or PCT treatment and may be passed the time of first 93 merchantability of trees for a CT treatment. The question for the forest managers is whether 94 further delaying CT from this point results in a higher economic benefit. Clearly, tree size has an 95 impact on the time consumption and profitability of harvesting equipment (Hiesl and Benjamin 96 2015; Hiesl and Benjamin 2013a; Kluender et al. 1998), and thus a delayed CT may be to the 97 financial advantage of a forest manager. In Maine, two fully mechanized harvesting systems are 98 predominantly used for timber harvesting: whole-tree (tracked feller-buncher, grapple skidder, 99 stroke delimber) and cut-to-length (harvester, forwarder) (Leon and Benjamin 2012). In addition, 100 some companies use a combination (hybrid) of the two systems. The use of such different 101 harvesting systems adds another dimension to the question of the economic benefit of a 102 delayed CT as each system has a different cost and productivity associated with it.

We used ten-year measurements and a 35 years growth projection from a controlled 104 experiment across six sites in Maine, to examine the long-term effect of CT removal intensity 105 and timing of CT application on maximum NPV. We expected that an early and heavy CT would 106 produce a higher maximum NPV due to early financial returns and increased merchantable 107 volume at the time of final harvest. We also expected to see the highest maximum NPV in 108 harvests conducted with a whole-tree harvesting system, due to its prevalence as the most 109 common harvesting system in Maine.

\section{METHODS}

112 Study Area

All sites are part of the University of Maine's Commercial Thinning Research Network 115 (CTRN), had been naturally regenerated, and previously received herbicide and PCT treatments 
116 (Wagner et al. 2001). Spruce-fir stand composition and structure are influenced by climatic 117 zone. Briggs and Lemin (1992) found that Maine is divided into nine climatic zones, and the 118 CTRN study sites represent three of the climatic zones of the north. Parent material of soils was 119 glacial till and alluvium (Ferwerda et al. 1997). All study sites were within the Acadian forest, a 120 conifer-dominated mixedwood ecosystem that covers much of Maine and the Canadian 121 Maritimes. Red spruce (Picea rubens Sarg.) and balsam fir (Abies balsamea (L.) Mill.) are the 122 most dominant tree species in these stands. Other conifer species include white spruce (Picea 123 glauca (Moench) Voss), eastern white pine (Pinus strobus L.), black spruce (Picea mariana 124 (Mill.) Britton, Sterns and Poggenburg), eastern hemlock (Tsuga Canadensis (L.) Carrière), and 125 northern white-cedar (Thuja occidentalis L.). Common hardwood species include red maple 126 (Acer rubrum L.), yellow birch (Betula alleghanensis Britt.), paper birch (Betula papyrifera 127 Marshall), and quaking aspen (Populus tremuloides Michx.).

Study Sites

All sites are located in central and northern Maine (Figure 1) and received a PCT 131 treatment between 1983 and 1985, were dominated by balsam fir, and consisted of good to 132 excellent site quality (16 - $21 \mathrm{~m}$ at 50 years breast-height) (Seymour et al. 2014; Clune 2013; 133 Wagner et al. 2001). Each site consisted of one control plot and six treatment plots including 134 two different removal intensities (33\% and $50 \%$ relative density removal) and three different 135 timings of entry (no-delay, 5-year delay, 10-year delay; Table 1) (McConville et al. 2003; 136 Wagner and Seymour 2000). Rectangular permanent plots, $809 \mathrm{~m}^{2}$ in size, were fully 137 inventoried on an annual or semi-annual basis between 2002 and 2012, and diameter at breast 138 height $(\mathrm{DBH})$ and total tree height were recorded for each tree greater than $5 \mathrm{~cm} \mathrm{DBH}$. Stand 139 density in 2012 ranged from 384 to 2,046 trees per ha, quadratic mean diameter (QMD) ranged 
140 from 15.4 to $23.3 \mathrm{~cm}$, basal area ranged from 12.2 to $46.4 \mathrm{~m}^{2} \cdot \mathrm{ha}^{-1}$, and average tree height 141 ranged from 12.1 to $16.6 \mathrm{~m}$ (Table 2).

The CTRN study was established in 2000 and 2001, but CT treatments were not applied

143 until 2002 (Wagner et al. 2002). All study sites in the CTRN were chosen based on a stand age 144 ready for a CT, a well-stocked and single-cohort stand structure with a relative density of greater 145 than 0.25 (Wilson et al. 1999) based on trees with a $\mathrm{DBH}$ larger than $6.3 \mathrm{~cm}$, and a good to 146 excellent site quality (Briggs site class 1, 2, or 2/3; Briggs 1994) (Wagner et al. 2001). 147 Therefore, individual trees were (1) in need of thinning due to high competition levels, (2) large 148 enough to generate enough revenue to pay for the thinning, and (3) had the ability to respond 149 favorably to thinning (e.g. strong vigor, low windthrow susceptibility, acceptable live-crown ratio). 150 However, stand age may have been past the initial timing of first merchantability. Due to the 151 varying degrees of site quality, the age of these stands at the beginning of the experiment in 1522000 ranged from 23 to 42 years, a range of age that was commonly encountered by forest 153 managers due to the clear cuts following the spruce budworm outbreak in the 1970s and 1980s 154 (Seymour 1992; Irland et al. 1988). The delayed treatments were used to evaluate the effect of 155 a delayed timing of entry on tree growth and NPV compared to a normal thinning close to the 156 time of first merchantability of a stand.

The seven plots in each site varied in their initial plot conditions. To ensure that the two 158 different removal intensities did not create thinned plots of similar conditions each plot was 159 ranked based on initial relative density. Plots with first and fifth highest relative density were 160 assigned a $33 \%$ and $50 \%$ relative density removal in the initial year of the study (2002), 161 respectively. The plot with the median relative density was selected as the untreated control plot 162 and the remaining plots were left unthinned during the first cutting cycle and were assigned 163 treatments for the 5 and 10 year delay based on the initial ranking (Wagner et al. 2001). The 
164 target relative density $( \pm 1 \%)$ in each plot was calculated using a laptop computer during leave 165 tree selection, which was based on the goal to retain most spruce and removal of all 166 hardwoods, balsam fir greater than $21.5 \mathrm{~cm} \mathrm{DBH}$, and any poor quality trees. The aim of the 167 thinning method was to represent a crown thinning. Following leave tree selection all remaining 168 trees greater than $11.3 \mathrm{~cm} \mathrm{DBH}$ were marked for removal. Additional information about the 169 experimental design can be found in Clune (2013) and Wagner et al. (2001).

171 Growth and Yield

172 Growth and yield for each plot was projected from plot measurements taken in 2012 173 (Table 2) for 35 years using the Acadian Variant of the Forest Vegetation Simulator (FVS-ACD) 174 (Weiskittel et al. 2012). This variant projects the growth and mortality of individual trees on an 175 annual basis using species-specific equations developed for the Acadian Region. In addition to 176 using FVS-ACD, we also included newly developed diameter, height, and height to crown base 177 increment and mortality modifiers for balsam fir and red spruce that adjust predicted growth and 178 mortality of individual trees based on information from the last commercial thinning 179 measurements (Kuehne et al. 2016; Weiskittel et al. 2015). These growth and mortality 180 modifiers rely on time since commercial thinning, \% basal area removed, and the ratio of QMD 181 post- and pre-thinning. We also used observed plot data measured in 2002, 2007, and 2012 to 182 calculate net present values for all treatments.

184 Product Merchandising

185 For every year in the projection we merchandised individual trees by using an $\mathrm{R}$ ( $\mathrm{R}$ Core 186 Team 2015) based product merchandiser developed by Hutchinson (2014). This merchandiser 187 estimates merchantable sawlog and pulpwood volume based on regional taper and volume 
equations (Weiskittel and Li 2012; Li et al. 2012). Biomass volume was not estimated or included in this study. Minimum top diameter for pulpwood for all relevant species was $10.2 \mathrm{~cm}$ with a minimum $\mathrm{DBH}$ of $12.7 \mathrm{~cm}$. For sawlogs the minimum top diameters were 19.3 and 24.4 $\mathrm{cm}$ with a minimum $\mathrm{DBH}$ of 22.9 and $27.9 \mathrm{~cm}$ for softwood and hardwood species, respectively. 192 These values are consistent with the merchantability specifications of the FVS Northeast 193 variant.

Harvest Cost and Revenue

The costs for CT were estimated using the approach outlined by Saunders et al. (2008).

197 They used a simplified version of the model of Randolph et al. (2001), who estimated CT 198 harvesting costs using PPHARVST harvest cost simulator (Fight et al. 1999). The thinning 199 system chosen by these authors was a cut-to-length (CTL) system with a machine rate of $200 \$ 74.56$ USD per productive machine hour $(\mathrm{PMH})$ for a harvester, and $\$ 51.88 \mathrm{USD}^{\mathrm{PMH}}{ }^{-1}$ for a 201 forwarder. As the majority of study sites were thinned using a CTL system (Wagner et al. 2001), 202 we believe that this method represented a good approximation of the real thinning costs. At the 203 time of thinning, harvest costs and volume removal were not recorded for all treatments and 204 sites, and thus for consistency throughout the projection, all removal costs and volumes were 205 estimated. Volume removal for each CT was estimated by using average piece size before the 206 thinning and the number of trees removed during the thinning (Table 3 ) in an equation provided 207 by Saunders et al. (2008). The average piece size was estimated by inserting QMD and stand 208 density before the thinning into an equation provided by Wilson et al. (1999) that was solved for 209 piece size. Saunders et al. (2008) also reported a mill delivered product value for pulpwood $210\left(\$ 147.23 \mathrm{USD} \cdot \mathrm{m}^{-3}\right)$ that was used for revenue calculation of the CT. This product value is from 211 Maine in the early 2000s and does not reflect current product values for pulpwood, which are 
212 between $\$ 40$ and $\$ 50$ USD $\cdot \mathrm{m}^{-3}$. To allow for the same effect of CT cost on NPV, the value used 213 by Saunders et al. (2008) was used in all CT estimations. Detailed information before and after 214 CT for all treatments can be found in Table 3.

215 To estimate final stand harvest costs, lists of trees created by the growth and yield 216 projection were expanded to represent a one-hectare harvest block for each plot. The growth 217 and yield projection returned such a list of trees for every year for 35 years. Each year's 218 projection was based on the previous year's tree list, starting with measured data from 2012. In 219 this projection, final stand harvest costs were estimated for every year following the CT, and 220 there was no definition of the final stand in terms of age. Harvest time for three harvesting 221 systems was estimated using regional cycle time equations for harvesting equipment (Hiesl and 222 Benjamin 2015; Hiesl 2013; Hiesl and Benjamin 2013a,b). A cut-to-length (CTL) system 223 consists of a harvester ( $\$ 160 \mathrm{USD} \cdot \mathrm{PMH}^{-1}$ (productive machine hour)) and forwarder $(\$ 110$ $224 \mathrm{USD} \cdot \mathrm{PMH}^{-1}$ ), a whole-tree (WT) system consists of a feller-buncher ( $\$ 140 \mathrm{USD} \cdot \mathrm{PMH}^{-1}$ ), grapple 225 skidder (\$100 USD $\cdot \mathrm{PMH}^{-1}$ ), and stroke delimber ( $\$ 130 \mathrm{USD} \cdot \mathrm{PMH}^{-1}$ ), and a hybrid (HYB) system 226 consists of a feller-buncher, processor $\left(\$ 160 \mathrm{USD} \cdot \mathrm{PMH}^{-1}\right.$ ), and forwarder (all machine rates 227 represent averages estimated as part of an early commercial thinning study in Maine (Benjamin 228 et al. 2013)). These systems were chosen as they represent harvesting equipment that is 229 commonly used in this region. A processor in a HYB system does not have to fell trees and 230 therefore uses less time to process individual trees. Processor cycle time of the HYB system 231 was estimated using $70 \%$ of the estimated harvester cycle time of a CTL system. Research by 232 Simões et al. (2008) suggests that a harvester spends approximately $30 \%$ of its time felling 233 trees. Time consumption for a loader/crane to load one truck was assumed to be $25 \mathrm{~min}$. We 234 used an average skidding and forwarding distance of $300 \mathrm{~m}$, a forwarder payload of $10 \mathrm{~m}^{3}$, and 235 a bunch size of $3 \mathrm{~m}^{3}$, which are consistent with regional values. 
Harvest costs were calculated using the estimated time consumption for each machine

237 multiplied with the appropriate machine rate (see previous paragraph). The machine rate for a 238 loader was assumed to be $\$ 40$ USD $\cdot \mathrm{PMH}^{-1}$. Cost of delivering roundwood to the mill at a round239 trip distance of $160 \mathrm{~km}$ and a cost of $\$ 1.67 \mathrm{USD} \cdot \mathrm{km}^{-1}$ were also included. This distance was 240 chosen as it represents a common trucking distance in Maine. Payload for one truck was 241 assumed to be $28 \mathrm{~m}^{3}$, to ensure that the truck and the load are within state specifications of 242 gross weight. Revenue was estimated for every year using the projected merchandised sawlog 243 and pulpwood volume from each plot and multiplying it with average mill delivered product 244 values of $\$ 72 \mathrm{USD} \cdot \mathrm{m}^{-3}$ for sawlogs and $\$ 42 \mathrm{USD} \cdot \mathrm{m}^{-3}$ for pulpwood. All product values are 245 based on information from the forest industry in Maine in 2014 . We did not adjust product value 246 for possible changes in the future.

Net present value (NPV) is the sum of all cash flows, positive or negative, discounted or 248 compounded to a base year $(=2002)$. In this study there were two cash flows: CT costs and 249 revenue, and final harvest costs and revenue (Eqn. 1). Other management costs of the stand, 250 such as PCT before 2002, reforestation, and future values past the final harvest were not 251 included.

(Eqn. 1)

$$
N P V\left(\$ \cdot h a^{-1}\right)=\frac{C T_{\text {gross }}-H C_{C T}}{(1+i)^{t_{1}-t}}+\frac{F H_{g r o s s}-H C_{F H}}{(1+i)^{t_{2}-t}}
$$
whereas $H C_{C T}$ and $H C_{F H}$ are the harvest costs associated with these treatments. The years of 257 CT, and final harvest are described by $t_{1}$, and $t_{2}$, respectively. The base year, $t$, is 2002 , the 
258 year of the decision making of whether to thin immediately or delay CT. We used a $4 \%$ discount 259 rate, $i$, based on the adopted recommendation of the US Forest Service in long-term resource 260 planning (Row et al. 1981). NPV was calculated for every potential final harvest year of the 261 projection.

Analytical Approach

264 To assess the influence of treatment on the value and timing of maximum NPV, we 265 developed two linear mixed-effect analysis of variance (ANOVA) models. Since the sites were 266 previously thinned by a CTL system (Wagner et al. 2001), we used a CTL system as our 267 baseline for NPV calculations. For the assessment of the influence of harvesting system and 268 treatment on maximum NPV, we developed an additional ANOVA model using NPV data from 269 all three harvesting systems simulated in this study. Random effects for plots nested within site 270 were estimated to account for variation from factors that have not been identified and may have 271 influenced the dependent variables. Pairwise comparison tests among thinning treatments and 272 controls were performed using Tukey's method of multiple comparisons at a significance level of 273 0.05. For the analysis of influence of harvesting system and treatment on maximum NPV we 274 conducted paired comparisons between all sites. All analyses were implemented in R (R Core 275 Team 2015) using the nIme (Pinheiro et al. 2015), multcomp (Hothorn et al. 2008), and Ismeans 276 (Lenth and Herve 2015) packages.

277 A sensitivity analysis for six major input variables (skidding distance, trucking distance, 278 trucking costs, pulpwood and sawlog value, and machine rates for the harvesting system) was 279 conducted by changing one input variable by $\pm 20 \%$ while holding all other input variables 280 constant. The percent change in maximum NPV for each change in input variable values was 
281 then calculated. The values described in this methods section for the projection of maximum 282 NPV were used as baseline values representing a $0 \%$ change in input variable and a $0 \%$ 283 change in maximum NPV.

\section{RESULTS}

Five variables were used to describe the response of spruce-fir stands to the various CT 287 treatments. Responses were measured and projected from the time of CT and included 288 merchantable volume (Figure 2a), merchantable volume mean annual increment (MAl; Figure $2892 \mathrm{2b}$ ), average merchantable stem size (Figure 2c), net present value (NPV; Figure 2d), and NPV 290 differences from the control (Figure 2e). Merchantable volume reached its peak between 29 and 29140 years after thinning for both the light (treatments $A-C$ ) and heavy thinning (treatments $D-F$ ), 292 regardless of the delay (Figure 2a). At its peak, merchantable volume ranged from 296 to 372 $293 \mathrm{~m}^{3} \cdot \mathrm{ha}^{-1}$ for light thinning, and from 212 to $246 \mathrm{~m}^{3} \cdot \mathrm{ha}^{-1}$ for heavy thinning. For both thinning 294 intensities the 10-year delay in thinning (treatments $\mathrm{C}$ and $\mathrm{F}$ ) produced the highest 295 merchantable volume. The untreated control plot reached its highest value of $437 \mathrm{~m}^{3} \cdot \mathrm{ha}^{-1}$ at 49 296 years after site establishment, but due to the limited projection time may not have reached its 297 peak yet. Merchantable volume MAI for all thinning treatments peaked 14 to 15 years after 298 thinning (Figure 2b). MAl for the control plot peaked 23 years after site establishment. Light 299 thinning (treatments A-C) had a larger peak MAl (5.1 to $5.6 \mathrm{~m}^{3} \cdot$ ha $^{-1} \cdot$ year $\left.^{-1}\right)$ than heavy thinning 300 (treatments D-F; 3.6 to $4.2 \mathrm{~m}^{3} \cdot \mathrm{ha}^{-1} \cdot \mathrm{year}^{-1}$ ). The control plot had the highest peak MAI with 6.4 $301 \mathrm{~m}^{3} \cdot \mathrm{ha}^{-1} \cdot \mathrm{year}^{-1}$. The average merchantable stem size in all treatments and the control plot 302 increased over time (Figure 2c). At the time of maximum NPV the average merchantable stem 303 size was $0.33 \mathrm{~m}^{3}$ for treatment $A, 0.36 \mathrm{~m}^{3}$ for treatment $B, 0.40 \mathrm{~m}^{3}$ for treatments $C, D$, and $E$, 
304 and $0.46 \mathrm{~m}^{3}$ for treatment $\mathrm{F}$. The average merchantable stem size for the control was much 305 smaller at $0.22 \mathrm{~m}^{3}$.

306 Maximum NPV over the projected life of a stand for light and heavy thinning was 307 reached 14 to 15 years after thinning (Figure 2d). For control plots the maximum NPVoccured 30814 years after CTRN establishment. The average maximum NPV differed in magnitude between 309 light and heavy thinning by up to $29 \%$. For light thinning, this NPV ranged from $\$ 6,067$ to $\$ 6,337$ $310 \mathrm{USD} \cdot \mathrm{ha}^{-1}$, and from $\$ 4,931$ to $\$ 5,709 \mathrm{USD} \cdot \mathrm{ha}^{-1}$ for heavy thinning. On average, the maximum 311 NPV for control plots was $\$ 4,889 \mathrm{USD} \cdot \mathrm{ha}^{-1}$.

\section{Treatment Effect on maximum NPV}

314 The ANOVA results suggested that treatment had a significant effect on maximum NPV $315\left(p_{\text {treatment }}=0.01\right.$; Table $\left.4 a\right)$, however, pairwise comparison's indicated that there was no statistical 316 difference (Table 5). Across all treatments and final harvest years, the maximum NPV ranged 317 from $\$ 3,611$ to $\$ 8,172 \mathrm{USD} \cdot \mathrm{ha}^{-1}$ (Table 5 ). Ninety-one percent of the random variation in 318 maximum NPV were accounted for differences at the site and plot-level within the individual 319 study sites (Table 4a).

321 Treatment Effect on Stand Age of maximum NPV

The ANOVA results showed that treatment had a significant effect $(p<0.001$; Table 4b)

323 on the stand age of maximum NPV. The average rotation length to reach maximum NPV across 324 all CT treatments ranged from 49 to 59 years (Table 5). Light and heavy thinning's resulted in a 325 rotation length of between 40 and 67 years, while control plots reached economic maturity, as 326 defined by reaching maximum NPV, at a rotation length between 39 and 59 years. Pairwise 327 comparison indicated that there were no differences between treatments $A$ and $D, B$ and $E$, and 
$328 \mathrm{C}$ and $\mathrm{F}$ (Table 5). This result indicates that there are no differences between the different 329 removal intensities in the stand age to reach maximum NPV. Since all treatments reached 330 maximum NPV at the same time after thinning it is not surprising that when NPV is plotted over 331 rotation age the maximum NPV for the delayed thinning occurred 5 (treatments B and E) or 10 332 years (treatments $\mathrm{C}$ and F) later than a CT with no delay (treatments $A$ and D). Approximately $33399 \%$ of the random variation can be explained by differences on the site and plot-level within the 334 individual sites (Table 4b).

Harvesting System Effect on maximum NPV

The ANOVA results indicated that treatment $(p=0.01)$, harvesting system $(p<0.001)$, and 338 their interaction $(p<0.001)$ had significant effects on maximum NPV (Table 4c). Maximum NPV 339 for all CT treatments ranged from $\$ 3,611$ to $\$ 8,172$ USD $\cdot$ ha $^{-1}$ when using a CTL system, from $340 \$ 3,269$ to $\$ 8,031 \mathrm{USD} \cdot \mathrm{ha}^{-1}$ when using a HYB system, and from $\$ 3,393$ to $\$ 7,783 \mathrm{USD} \cdot \mathrm{ha}^{-1}$ 341 when using a WT system. Pairwise comparisons within each individual CT treatments and 342 control plots indicated that using a CTL system resulted in a higher maximum NPV than using a 343 HYB system or a WT system, with the exception of control plots (Figure 3). In the control, there 344 was no significant difference in maximum NPV between a HYB and WT system. The differences 345 in maximum NPV among thinning treatments between using a CTL and WT system ranged from $346 \$ 215$ to $\$ 322$ USD $\cdot \mathrm{ha}^{-1}$, and from $\$ 83$ to $\$ 189$ USD $\cdot \mathrm{ha}^{-1}$ when comparing a CTL to a HYB 347 system. In the control, the average difference between CTL and WT was \$298 and \$334 348 USD ha $^{-1}$ when comparing CTL to HYB. Thus, a final harvest using a CTL system returned a 349 maximum NPV that was between $4.5 \%$ and $6.3 \%$ higher than that of a WT system, and between $3501.7 \%$ and $7.1 \%$ higher than that of a HYB system. All of the random variation in the data was 351 captured by site and plot-level differences between the sites (Table 4c). 
Differences between harvesting systems were influenced by the unit cost of production

353 based on average stem diameter (Figure 4). The CTL system consistently had a lower unit cost

354 of production than either the WT or HYB system, regardless of average merchantable stem

355 size. For merchantable stem sizes ranging from approximately 0.15 to $0.25 \mathrm{~m}^{3}$ the WT system

356 had a lower unit cost of production than a HYB system, however, outside of this range, a WT

357 system had the highest unit cost of production of all three harvesting systems (Figure 4).

358 Average merchantable stem size in 2002 was approximately $0.15 \mathrm{~m}^{3}$ for all treatments, 359 indicating that in comparison with the unit cost in Figure 4, the CTL system was the best choice 360 for CT at the time of study begin.

\section{Sensitivity of maximum NPV}

To understand the robustness of our analysis we conducted a sensitivity analysis of the major input variables (skid distance, trucking distance, trucking costs, pulpwood value, sawlog value, machine rate) that affect unit cost of production. Results for treatment $A$ showed that a change in mill delivered value of sawlogs had the greatest impact on maximum NPV (Figure 5).

367 For example, a $20 \%$ decrease in sawlog value resulted in an $18 \%$ decrease in maximum NPV. 368 Pulpwood value had the second largest impact on maximum NPV, with a $20 \%$ decrease in 369 pulpwood value resulting in an $8 \%$ decrease in maximum NPV. A $20 \%$ decrease in the machine 370 rate for all equipment in a harvesting system resulted in a $6 \%$ increase of maximum NPV. 371 Trucking cost, trucking distance, and skidding distance affected maximum NPV by less than 5\%

372 for a $20 \%$ change in the respective input variable. For all other treatments $(B-F)$ the relationship 373 was approximately the same, however, an increase in the sensitivity to pulpwood value was

374 noted in treatments $\mathrm{C}$ and F. For control plots, the sensitivity to changes in pulpwood value was

375 the greatest (Figure 5). For a $20 \%$ decrease in pulpwood value the maximum NPV decreased 
376 by $20 \%$. A $20 \%$ decrease in sawlog value would result in an $18 \%$ decrease in maximum NPV. 377 Changes in machine rate when operating in control plots had a higher impact on maximum NPV 378 than for any treatment. A $20 \%$ reduction in machine rate resulted in a $10 \%$ increase in maximum 379 NPV. Trucking cost and trucking distance had a greater effect on maximum NPV in the control 380 than it had in any other treatment. In light and heavy thinning treatments, the effect of trucking 381 cost and trucking distance on maximum NPV is generally less than $5 \%$, whereas in control plots 382 the effect is closer to $7.5 \%$ for a $20 \%$ change in the respective input variable. Skidding distance 383 had a slightly larger impact on maximum NPV in the control than in any thinning treatment. 384 However, the difference in maximum NPV between control and thinning treatments is only $1 \%$ 385 for a $20 \%$ change in skidding distance.

\section{DISCUSSION}

Commercial Thinning Effects

Our results indicated that there was no difference in maximum NPV among the CT treatments and control plots. Thus, delaying CT, or increasing removal intensity, did not result in 391 a higher maximum NPV. However, a delayed and light CT (treatments B and C) resulted in the 392 highest maximum standing merchantable volume among thinned stands.

A previous study of the same sites with data until 2010 indicated that treatment B 394 produced the highest average of standing total volume across the first 5 years post thinning 395 (Clune 2013). At the time of that study, treatment $C$ was not yet conducted and therefore was 396 not included by Clune (2013). Our analysis showed that treatment C returned the highest 397 merchantable volume. Clune (2013) also reported that the merchantable volume for treatments 398 A to $C$ was higher than for treatments D to F. Our results showed the same trend; however, the 
399 additional volume was not enough to cause a significantly higher maximum NPV. This finding 400 can be attributed to the fact that treatments $D$ to $F$ resulted in a greater sawlog percentage at 401 the time of final harvest, which are valued at a higher price.

Delaying the first CT by 5 or 10 years had no effect on maximum NPV for the delayed treatments. Consequently, it was possible to achieve a similar profit whether or not a CT was delayed from the point a stand was ready for thinning, regardless of the actual time past first 407 merchantability in this study. Thus, there is a window of opportunity of 10 years to conduct a CT 408 without an economic loss. However, the time when maximum NPV was achieved is of 409 importance, as this can have implications on the rotation length of a stand. For all treatments, 410 the time to reach maximum NPV after a CT was not significantly different between them. 411 However, this time did not include the additional 5 or 10 years that trees were growing before 412 they were thinned, and thus the rotation time is significantly different between the three timings 413 of entry for the light and heavy thinning's. When including this additional growing time, the 10414 year delay in thinning resulted in the longest rotation time to reach maximum NPV, regardless of 415 removal intensity.

A CT is used to reduce stand density and focus diameter growth on a smaller number of 417 trees (Smith 1986; Nyland 2002). Research in Maine and the surrounding area confirms that CT 418 generally increases stem diameter and volume growth on a reduced number of trees in spruce 419 plantations (Pelletier and Pitt 2008). However, research on Norway spruce (Picea abies L.) 420 stands in Finland showed that a delayed thinning reduced basal area increment when compared 421 with CT at a normal time or with intensive CT (Jaakkola et al. 2006). Saunders et al. (2008) 
422 reported that unthinned controls were not able to "catch up" with PCT stands within the same 423 rotation length. They also showed that the NPV of control plots was lower and culminated later. 424 Similar findings were also reported by Bataineh et al. (2013) when using a 2\% discount rate. In 425 our study, however, the NPV of the control was no different than any of the CT treatments, and 426 did culminate at the same time as treatments that were thinned with no delay.

Choice of Harvesting System

We also evaluated the use of three different harvesting systems. Since a WT harvesting 430 system is the most commonly used system in Maine (Leon and Benjamin 2012) we aimed to 431 investigate whether alternative systems would be economically feasible. The results showed 432 that a CTL harvesting system resulted in the highest NPV across all three harvesting systems 433 tested. This is a surprising result, as approximately $80 \%$ of Maine's timber volume is processed 434 by WT harvesting systems (Leon and Benjamin 2012). With a significant difference of several 435 hundred dollars per ha, greater use of CTL systems would be expected. One of the reasons for 436 the high percentage of timber processed by WT systems might be the initially higher costs for 437 CTL equipment, and the greater complexity to operate such equipment. Harvesters and 438 forwarders can be several hundred thousand dollars more expensive than other machines 439 (Rankin 2015). Another factor that affect harvest costs is stem size (Kluender et al. 1998; 440 Adebayo et al. 2007; Lageson 1997). The unit cost of production generally decreases with 441 increasing stem size. Our results showed that stem size had a major effect on unit cost of 442 production and that a CTL system consistently had lower costs than the WT or HYB system. 443 However, at small stem sizes the WT system produced at a lower cost than a HYB system, 444 which may be due to the larger number of stems per feller-buncher accumulation (Hiesl and 
445 Benjamin 2013a) when thinning a small diameter stand. The fact that the average merchantable 446 stem size at the age of maximum NPV in the control was around $0.22 \mathrm{~m}^{3}$, a value for which unit 447 cost of production is similar between WT and HYB systems, may explain the similar maximum $448 \quad$ NPV between the two systems.

Our results also indicated that a HYB system consisting of a feller-buncher, processor, 450 and forwarder returned a lower maximum NPV than a CTL system for CT treatments. This result 451 was unexpected because the HYB system is considered to be less expensive than a CTL 452 system, mainly due to the high productivity of the feller-buncher and the concentrated 453 processing of trees. One of the major reasons for this result may be the fact that the forwarder 454 cycle time equation used did not account for spacing between logs but was developed based on 455 commonly encountered conditions during thinnings. The conditions commonly encountered 456 include a varying log spacing that was not measured but is known to be much farther than what 457 actually would be present on site when using a HYB system. Log concentration at a harvest site 458 has been shown to influence forwarder productivity (Manner et al. 2013) and therefore the 459 actual forwarder productivity for a HYB system might be higher, due to fewer stops and a larger 460 payload per stop. Currently, however, there are no forwarder equations available for this state 461 that would include log spacing as a determining factor.

One of the limitations of this simulation was that we did not include any costs associated 463 with moving harvesting equipment to the harvest site, or any administrative or road 464 building/maintenance costs. Including these costs is difficult as they are highly variable and 465 depend on factors such a distance from a logging contractor and road conditions, but also affect 466 NPV differently with increasing harvest tract size. It is therefore important to highlight that the 467 NPVs presented here are likely rather optimistic projections, and will probably be smaller due to 468 additional costs that were not included in this simulation. In addition, we did not include future 
469 forest values in our analysis and limited our study to only one rotation. By including future forest 470 values into these calculations, the maximum NPV would typically be reached earlier.

\section{Influence of Study Design}

The study design of the CTRN (Wagner et al. 2001) may have a significant influence on

473 our results. Treatments were assigned based on relative density to avoid treatments with a low

474 removal intensity to produce a similar residual stand as high removal intensity treatments. Thus,

475 heavy removal intensities (treatments D-F) were always associated with a higher initial relative

476 density as compared to light removal intensities (treatments A-C). This stratification may limit

477 the ability to predict results for different management scenarios such as a light thinning in a 478 dense stand. Emmingham et al. (2007) found that in natural Douglas fir (Pseudotsuga menziesii 479 (Mirb.) Franco) stands the growth rates of residual stands depended on the amount of residual 480 growing stock. Their results indicated that dominant and codominant trees provided the majority 481 of net volume growth. In our study, a crown thinning was performed (Wagner et al. 2001), which 482 may remove a greater number of dominant and codominant trees, and thus reduce the potential 483 net volume growth, as compared to a low thinning like evaluated in Emmingham et al. (2007).

484 In addition, the study in the CTRN may have started past the time of first merchantability 485 of stands, as may be indicated by the various stand ages at time of study establishment 486 (Wagner et al. 2001). Harvest costs are strongly influenced by stem size, with a higher stem 487 size reducing the overall unit cost of production (Kluender et al. 1998; Lageson 1997). Larger 488 stem size, however, also results in a higher value of the individual tree. Both factors strongly 489 affect NPV calculations and thus, stand conditions at the beginning of the study need to be 490 considered when applying our results to other areas. However, due to the clear cuts occurring 491 during and after the spruce budworm outbreak in the 1970s and 1980s (Griffith and Alerich 
492 1996; Seymour 1992; Irland et al. 1988), the stand conditions represented in the CTRN study 493 were commonly encountered by foresters in northern Maine. In addition, the change of 494 ownership from forest industry to Timber Investment Management Organizations (TIMO) and 495 Real Estate Investment Trusts (REIT) in the 1990s (Jin and Sader 2006; McWilliams et al. 2005) 496 often forced forest managers to deal with stands that were past the first time of merchantability.

For our projection, we assumed that the machine rate and product values remained 500 constant over a 35-year period; however, there may be significant changes in these values over 501 time. Further, the model used for growth projection has been parameterized with growth and 502 mortality CTRN data over a 10 year period post-treatment (Kuehne et al. 2016), and thus 503 extrapolations beyond 10 years post-treatment may have significant effects on the results. It is 504 therefore crucial to acknowledge that the costs and revenues of the final harvest might be 505 different from the presented results. This difference in harvest costs can easily negate the 506 benefit of CT in terms of maximum NPV. Our sensitivity analysis indicated that changes in 507 product value and machine rate had the largest impact on maximum NPV. In particular, the 508 influence of pulpwood value was the largest in the control, which can be attributed to smaller 509 stem sizes and thus a higher volume of pulpwood as compared to other treatments. The control 510 also showed a higher sensitivity to machine rate, which may be attributed to a lower productivity 511 when cutting small diameter stems. It is important to note that for all CT treatments a financial 512 return was provided during the $\mathrm{CT}$, whereas the control plots did not yield any financial return 513 until final harvest. This is an important consideration for forest managers that require an early 514 financial return. 
515 The assumptions made in this projection were important factors that can influence the 516 long-term financial returns from CT (e.g. product values at time of CT and at final harvest). We 517 used average skidding distances and bunch sizes for softwood stands in Maine, based on 518 published and unpublished information from research by Hiesl (2013) and Hiesl et al. (2015). 519 Stand and site conditions, harvesting equipment, and extracting distances are just a few factors 520 that influence machine productivity and vary greatly among states and countries (Hiesl and 521 Benjamin 2013c). Thus, the assumptions used for the simulation may not be appropriate for 522 some neighboring jurisdictions. For example, the maximum skidding distance in Maine is 523 approximately $800 \mathrm{~m}$, while a common skidding distance in the state of New York can easily 524 exceed 1,600 m (personal communication with Dr. Steve Bick, principal consultant, Northeast 525 Forests, LLC., Thendara, NY).

Depending on the distance to a mill, average tree diameter, and other factors, the 527 stumpage rate for a given parcel of land can fluctuate substantially. For example, the stumpage 528 rate for spruce/fir pulpwood used by Bataineh et al. (2013) was \$11 USD·ton ${ }^{-1}$, which was the 529 average stumpage rate reported by the Maine Forest Service in 2010 (Maine Forest Service 530 2011). The reported range of 2010 stumpage rates for pulpwood in Maine Forest Service 531 (2011), however, was from $\$ 0.22$ up to $\$ 40$ USD $\cdot$ ton $^{-1}$. These stumpage rates are self-reported 532 annually by loggers, landowners, and foresters, and represent a wide range of stand and site 533 conditions. Therefore, using the average stumpage rate for any parcel might not be 534 representative at all. 


\section{CONCLUSION}

With the limitations of our experimental design, model outcomes, and assumptions as a 538 caution, we conclude that there is a margin for CT of approximately 10 years where there will be 539 no reduction in maximum NPV. However, due to the different stand ages and level of

540 merchantability at the beginning of the study we do not know whether or not a CT starting at first

541 merchantability would have resulted in a different maximum NPV. With a scope of 10 years past

542 study initiation, we also do not know whether a thinning with a greater delay would have 543 resulted in any change in maximum NPV. Thus, our results provide initial information for

544 decision makers, but further research is needed to fully understand the implications of delays 545 and thinning intensity on NPV and subsequently on the decision making process of forest 546 managers. The results also highlight the complexities associated with developing effective CT 547 strategies given variation in available markets, stumpage rates, and harvesting systems.

\section{ACKNOWLEDGEMENTS}

550 We would like to thank the Cooperative Forestry Research Unit (CFRU) at the University of

551 Maine for providing stand and plot level data for this project. In addition, Clemson University is 552 acknowledged for the generous allotment of computation time on the Palmetto cluster. Funding 553 for this project was provided by the University of Maine - School of Forest Resources. Thanks 554 to two anonymous reviewers and Associate Editor who helped to significantly improve previous 555 versions of this manuscript. 


\section{REFERENCES}

558

559

560

561

562

563

564

565

566

567

568

569

570

571

572

573

574

575

576

577

578

579

580

581

582

583

584

585

586

587

588

589

590

591

592

593

594

Adebayo, A.B., Han, H.-S. and Johnson, L. 2007. Productivity and Cost of Cut-to-length and Whole-tree Harvesting in a Mixed-conifer Stand. For. Prod. J. 57(6): 59-69.

Baskerville, G.L. 1959. Establishment Report - Cleaning and Thinning Young Fir. Department of Northern Affairs and National Resources, Forestry Branch, Maritimes District. Technical Report Project M-443-59.

Bataineh, M.M., Wagner, R.G. and Weiskittel, A.R. 2013. Long-term Response of Spruce-fir Stands to Herbicide and Precommercial Thinning: Observed and Projected Growth, yYeld, and Financial Returns in Central Maine, USA. Can. J. For. Res. 43(4): 385-395. Available from: http://www.nrcresearchpress.com/doi/abs/10.1139/cjfr-2012-0343 [accessed 31 July 2013].

Benjamin, J.G., Seymour, R.S., Meacham, E. and Wilson, J.S. 2013. Impact of Whole-tree and Cut-to-length Harvesting on Postharvest Condition and Logging Costs for Early Commercial Thinning in Maine. North. J. Appl. For. 30(4): 149-155.

Briggs, R.D. 1994. Site Classification. Maine Agricultural and Forest Experiment Station.

Briggs, R.D. and Lemin, R.C. 1992. Delineation of Climatic Regions in Maine. Can. J. For. Res. 22(6): 801-811.

Clune, P.M. 2013. Growth and Development of Maine Spruce-fir Forests Following Commercial Thinning. M.Sc. thesis, School of Forest Resources, University of Maine.

Emmingham, W., Fletcher, R., Fitzgerald, S. and Bennett, M. 2007. Comparing Tree and Stand Volume Growth Response to Low and Crown Thinning in Young Natural Douglas-fir Stands. West. J. Appl. For. 22(2): 124-133.

Ferwerda, J.A., LaFlamme, J.K.J., N.R. Kalloch, J. and Rourke, R.V. 1997. The Soils of Maine. Maine Agricultural and Forest Experiment Station. MAFES Miscellaneous Report 402.

Fight, R.D., Gicqueau, A. and Hartsough, B.R. 1999. Harvesting Costs for Management Planning for Ponderosa Pine Plantations. U.S. Department of Agriculture Forest Service, Pacific Northwest Research Station. General Technical Report PNW-GTR-467.

Griffith, D.M. and Alerich, C.L. 1996. Forest Statistics for Maine, 1995. Forest Inventory and Analysis Unit, Northeastern Forest Experiment Station, USDA Forest Service. Resource Bulletin NE-135.

Hiesl, P. 2013. Productivity Standards for Whole-tree and Cut-to-length Harvesting Systems in Maine. M.Sc. thesis, School of Forest Resources, University of Maine.

Hiesl, P. and Benjamin, J.G. 2013a. A Multi-stem Feller-buncher Cycle-time Model for Partial Harvest of Small Diameter Wood Stands. Int. J. For. Eng. 24(2): 101-108. doi:http://dx.doi.org/10.1080/14942119.2013.841626.

Hiesl, P. and Benjamin, J.G. 2013b. Harvesting Equipment Cycle Time and Productivity Guide for Logging Operations in Maine. Maine Agricultural and Forest Experiment Station. Miscellaneous Publications 762. 
595

596

597

598

599

600

601

602

603

604

605

606

607

608

609

610

611

612

613

614

615

616

617

618

619

620

621

622

623

624

625

626

627

628

629

630

631

632

633

Hiesl, P. and Benjamin, J.G. 2013c. Applicability of International Harvesting Equipment Productivity Studies in Maine, USA: A Literature Review. Forests 4(4): 898-921. doi:10.3390/f4040898.

Hiesl, P. and Benjamin, J.G. 2015. Estimating Processing Times of Harvesters in Thinning Operations in Maine. For. Prod. J. 65(3/4): 180-186.

Hiesl, P., Benjamin, J.G. and Roth, B.E. 2015. Evaluating Harvest Costs and Profit of Commercial Thinnings in Softwood Stands in West-central Maine: A Case Study. For. Chron. 91(2): 150-160.

Hothorn, T., Bretz, F. and Westfall, P. 2008. Simultaneous Inference in General Parametric Models. Biometrical J. 50(3): 346-363.

Hutchinson, S.F. 2014. Evaluating Variation in Commercial Timber and Land Value for Parcels in the Northeast United States. M.Sc. thesis, School of Forest Resources, University of Maine.

Irland, L.C., Dimon, J.B., Baum, E., Falk, J. and Stone, J.L. 1988. The Spruce Budworm Outbreak in Maine in the 1970's - Assessment and Directions for the Future. Maine Agricultural Experiment Station. Bulletin 819.

Jaakkola, T., Mäkinen, H. and Saranpää, P. 2006. Wood Density of Norway Spruce: Responses to Timing and Intensity of First Commercial Thinning and Fertilisation. For. Ecol. Manage. 237(1-3): 513-521. doi:10.1016/j.foreco.2006.09.083.

Jin, S. and Sader, S.A. 2006. Effects of Forest Ownership and Change on Forest Harvest Rates, Types and Trends in Northern Maine. For. Ecol. Manage. 228(1-3): 177-186. Available from: http://linkinghub.elsevier.com/retrieve/pii/S0378112706001691 [accessed 15 December 2014].

Kluender, R., Lortz, D., McCoy, W., Stokes, B. and Klepac, J. 1998. Removal Intensity and Tree Size Effects on Harvesting Cost and Profitability. For. Prod. J. 48(1): 54-59.

Kuehne, C., Weiskittel, A.R., Wagner, R.G. and Roth, B.E. 2016. Development and Evaluation of Individual Tree- and Stand-level Approaches for Predicting Spruce-fir Response to Preand Commercial-thinning in Maine, USA. For. Ecol. Manage. 376: 84-95. Available from: http://dx.doi.org/10.1016/j.foreco.2016.06.013.

Lageson, H. 1997. Effects of Thinning Type on the Harvester Productivity and on the Residual Stand. J. For. Eng. 8(2): 7-14.

Lenth, R. V and Herve, M. 2015. Ismeans: Least-Squares Means. R package version 2.16. Available from: http://cran.r-project.org/package=Ismeans.

Leon, B. and Benjamin, J.G. 2012. A Survey of Business Attributes, Harvest Capacity and Equipment Infrastructure of Logging Businesses in the Northern Forest. University of Maine. The Northern Forest Logging Industry Assessment.

Li, R., Weiskittel, A., Dick, A.R., Jr, J.A.K. and Seymour, R.S. 2012. Regional Stem Taper Equations for Eleven Conifer Species in the Acadian Region of North America: Development and Assessment. North. J. Appl. For. 29(1): 5-14. 
634

635

636

637

638

639

640

641

642

643

644

645

646

647

648

649

650

651

652

653

654

655

656

657

658

659

660

661

662

663

664

665

666

667

668

669

670

671

672

Maine Forest Products Council. 2013. Maine's Forest Economy. Maine Forest Products Council. Available from: http://maineforest.org/wp-content/uploads/2014/04/Maines-ForestEconomy.pdf.

Maine Forest Service. 2011. 2010 Stumpage Prices. Department of Conservation, Maine Forest Service, Forest Policy and Management Division. Annual Report.

Maine Forest Service. 2014. 2012 Wood Processor Report. Department of Agriculture, Conservation and Forestry - Maine Forest Service - Forest Policy and Management Division. Annual Report [Updated March 12, 2014].

Mäkinen, H. and Isomäki, A. 2004a. Thinning Intensity and Growth of Norway Spruce Stands in Finland. Forestry 77(4): 349-364. doi:10.1093/forestry/77.4.349.

Mäkinen, H. and Isomäki, A. 2004b. Thinning Intensity and Growth of Scots Pine Stands in Finland. For. Ecol. Manage. 201(2-3): 311-325. Available from: http://linkinghub.elsevier.com/retrieve/pii/S0378112704005328.

Manner, J., Nordfjell, T. and Lindroos, O. 2013. Effects of the Number of Assortments and Log Concentration on Time Consumption for Forwarding. Silva Fenn. 47(4): 1-19.

McConville, D.J., Wagner, R.G. and Seymour, R.S. 2003. Study Site Establishment and Measurement of the Commercial Thinning Research Network. In Cooperative Forestry Research Unit 2003 Annual Report. Edited by D.J. McConville. University of Maine, Orono, ME, USA. pp. 24-25.

McWilliams, W.H., Butler B.J., Griffith, D.M., Hoppus, M.L., Lister, A.J., Lister, T.W., Morin, R.S., Stewart, L.B. and Westfall, J.A. 2005. The Forests of Maine: 2003. U.S. Department of Agriculture Forest Service, Northeastern Research Station. Resource Bulletin NE-164.

Newton, M., Cole, E.C., McCormack, M.L. and White, D.E. 1992a. Young Spruce-Fir Forests Released by Herbicides II. Conifer Response to Residual Hardwoods and Overstocking. North. J. Appl. For. 9(4): 130-135.

Newton, M., Cole, E.C., White, D.E. and McCormack, M.L. 1992b. Young Spruce-Fir Forests Released by Herbicides I . Response of Hardwoods and Shrubs. North. J. Appl. For. 9(4): $126-130$.

Nyland, R.D. 2002. Silviculture: Concepts and Applications. 2nd ed. McGraw-Hill, New York, NY, USA. pp. 682.

Pekol, J.R. 2011. The Influence of Commercial Thinning on Stand- and Tree-level Mortality Patterns of Balsam Fir (Abies balsamea) and Red Spruce (Picea rubens) Forests in Maine That Have or Have not Received Precommercial Thinning. Master thesis.

Pelletier, G. and Pitt, D.G. 2008. Silvicultural Responses of Two Spruce Plantations to Midrotation Commercial Thinning in New Brunswick. Can. J. For. Res. 38(4): 851-867. Available from: http://www.nrcresearchpress.com/doi/abs/10.1139/X07-173 [accessed 9 September 2013].

Pinheiro, J., Bates, D., DebRoy, S., Sarkar, D. and R Core Team. 2015. nlme: Linear and Nonlinear Mixed Effects Models. R package version 3.1-120. Available from: http://cran.r- 
project.org/package=nlme.

674

675

676

677

678

679

680

681

682

683

684

685

686

687

688

689

690

691

692

693

694

695

696

697

698

699

700

701

702

703

704

705

706

707

708

709

710

711

Pitt, D.G. and Lanteigne, L. 2008. Long-term Outcome of Precommercial Thinning in Northwestern New Brunswick: Growth and Yield of Balsam Fir and Red Spruce. Can. J. For. $\quad$ Res. 38(3): 592-610. Available from: http://www.nrcresearchpress.com/doi/abs/10.1139/X07-132 [accessed 13 August 2013].

Pitt, D.G., Lanteigne, L., Hoepting, M.K. and Plamondon, J. 2013a. Effects of Precommercial Thinning on the Forest Value Chain in Northwestern New Brunswick: Part 1 - Roundwood Production and Stumpage Value. For. Chron. 89(4): 446-457.

Pitt, D.G., Lanteigne, L., Hoepting, M.K., Plamondon, J., Duchesne, I., Bicho, P. and Warren, G. 2013b. Effects of Precommercial Thinning on the Forest Value Chain in Northwestern New Brunswick: Part 6 - Estimating the Economic Benefits. For. Chron. 89(4): 502-511.

Plamondon, J. and Pitt, D.G. 2013. Effects of Precommercial Thinning on the Forest Value Chain in Northwestern New Brunswick: Part 2 - Efficiency Gains in Cut-to-length Harvesting. For. Chron. 89(4): 458-463.

Prévost, M. and Gauthier, M.M. 2012. Precommercial Thinning Increases Growth of Overstory Aspen and Understory Balsam Fir in a Boreal Mixedwood Stand. For. Ecol. Manage. 278: 17-26. doi:10.1016/j.foreco.2012.05.005.

R Core Team. 2015. R: A Language and Environment for Statistical Computing. R Foundation for Statistical Computing. Available from: http://www.r-project.org/.

Randolph, K.C., Seymour, R.S. and Wagner, R.G. 2001. ThinME: User's Guide. University of Maine. Cooperative Forestry Research Unit Report 357. Available from: http://library.umaine.edu/cfru/pubs/CFRU357.pdf.

Rankin, J. 2015. Mechanical harvesting - The Future is Here. For. Maine's Futur. Available from: http://www.forestsformainesfuture.org/fresh-from-the-woods-journal/mechanical-harvestingthe-future-is-here.html [accessed 1 January 2015].

Reukema, D.L. and Bruce, D. 1977. Effects of Thinning on Yield of Douglas-fir: Concepts and Some Estimates Obtained by Simulation. U.S. Department of Agriculture Forest Service, Pacific Northwest Research Station. General Technical Report PNW-GTR-58.

Row, C., Kaiser, H.F. and Sessions, J. 1981. Discount Rate for Long-Term Forest Service Investments. J. For. 79(6): 367-376.

Saunders, M.R., Wagner, R.G. and Seymour, R.S. 2008. Thinning Regimes for Spruce-Fir Stands in the Northeastern United States and Eastern Canada. Cooperative Forestry Research Unit.

Seymour, R.S. 1992. The Red Spruce-Balsam Fir Forest of Maine: Evolution of Silvicultural Practice in Response to Stand Developement Patterns and Disturbances. In The Ecology and Silviculture of Mixed-species forests. A festschrift for David M. Smith. Edited by M.J. Kelty, B.C. Larson, and C.D. Oliver. Kluwer Publishers, Norwell, MA. pp. 217-244.

Seymour, R.S., Meyer, S.R. and Wagner, R.G. 2014. The Cooperative Forestry Research Unit Commercial Thinning Research Network: 9-year Results. In Penobscot Experimental 
Forest: 60 years of research and demonstration in Maine, 1950-2010. GTR-NRS-P-123. Edited by L.S. Kenefic and J.C. Brissette. U.S. Department of Agriculture Forest Service, Northern Research Station, Newtown Square, PA. pp. 81-90.

Simões, D., Marcelino, F.A., Pletsch, T.A., De Faria, L.R. and Fenner, P.T. 2008. Technical and Economical Evaluation of Harvester Cut-to-length System in First Cut Eucalyptus Forest. Proceedings of CIGR International Conference of Agricultural Engineering. XXXVII Congresso Brasileiro De Engenharia Agricola - CONBEA.

Smith, D.M. 1986. The Practice of Silviculture. 8th ed. John Wiley \& Sons, Inc, New York, NY. pp. 527.

Wagner, R.G. and Seymour, R.S. 2000. Commercial Thinning Research Network. In Cooperative Forestry Research Unit 2000 Annual Report. Edited by H.E. Griffin. University of Maine, Orono, ME, USA. pp. 21-27.

Wagner, R.G., Seymour, R.S. and McConville, D.J. 2001. Commercial Thinning Research Network. In Cooperative Forestry Research Unit 2001 Annual Report. Edited by H.E. Griffin. University of Maine, Orono, ME, USA. pp. 23-35.

Wagner, R.G., Seymour, R.S., McConville, D.J. and Opland, D.M. 2002. Commercial Thinning Research Network. In Cooperative Forestry Research Unit 2002 Annual Report. Edited by University of Maine, Orono, ME, USA. pp. 23-28.

Wagner, R.G., Little, K.M., Richardson, B. and Mcnabb, K. 2006. The Role of Vegetation Management for Enhancing Productivity of the World's Forests. Forestry 79(1): 57-79. Available from: http://forestry.oxfordjournals.org/cgi/doi/10.1093/forestry/cpi057 [accessed 9 September 2013].

Weiskittel, A.R., Kenefic, L.S., Li, R. and Brissette, J. 2011. Stand Structure and Composition 32 years after Precommercial Thinning Treatments in a Mixed Northern Conifer Stand in Central Maine. North. J. Appl. For. 28(2): 92-96.

Weiskittel, A.R., Russell, M.B., Wagner, R.G. and Seymour, R.S. 2012. Refinement of the Forest Vegetation Simulator Northeast Variant Growth and Yield Model: Phase III. In Cooperative Forestry Research Unit 2011 Annual Report. Edited by B.E. Roth. University of Maine, Orono, ME, USA. pp. 85-93.

Weiskittel, A. and Li, R. 2012. Development of Regional Taper and Volume Equations: Hardwood Species. In Cooperative Forestry Research Unit 2011 Annual Report. Edited by B.E. Roth. University of Maine, Orono, ME, USA. pp. 87-95.

Weiskittel, A.R., Hennigar, C. and Kershaw, Jr., J.A. 2015. Extending the Acadian Variant of FVS to Managed Stands. In Cooperative Forestry Research Unit 2014 Annual Report. Edited by R.G. Wagner. University of Maine, Orono, ME, USA. pp. 47-51.

Wilson, D.S., Seymour, R.S. and Maguire, D.A. 1999. Density Management Diagram for Northeastern Red Spruce and Balsam Fir Forests. North. J. Appl. For. 16(1): 48-56.

Zeide, B. 2001. Thinning and Growth: A Full Turnaround. J. For. 99(1): 20-25. Available from: http://www.ingentaconnect.com/content/saf/jof/2001/00000099/00000001/art00005Inhttp:// 
751 search.ebscohost.com/login.aspx?direct=true\&db=agr\&AN=IND22086145\&site=ehost-live.

752 Zhang, S., Chauret, G. and Tong, Q. 2009. Impact of Precommercial Thinning on Tree Growth, 753 Lumber Recovery and Lumber Quality in Abies Balsamea. Scand. J. For. Res. 24(5): 425754 433. Available from: http://www.tandfonline.com/doi/abs/10.1080/02827580903124392 $755 \quad$ [accessed 4 February 2013]. 
Table 1: Description of all treatments and control plots.

\begin{tabular}{|c|c|}
\hline Treatment & Description \\
\hline $\mathrm{A}$ & $\begin{array}{l}33 \% \text { relative density reduction with no-delay in thinning. } \\
\text { Thinning was done in } 2002 \text {. Average basal area removal was } \\
40 \% \text {. }\end{array}$ \\
\hline $\mathrm{B}$ & $\begin{array}{l}33 \% \text { relative density reduction with a } 5 \text {-year delay in thinning. } \\
\text { Thinning was done in } 2007 \text {. Average basal area removal was } \\
40 \% \text {. }\end{array}$ \\
\hline $\mathrm{C}$ & $\begin{array}{l}33 \% \text { relative density reduction with a } 10 \text {-year delay in thinning. } \\
\text { Thinning was done in } 2012 \text {. Average basal area removal was } \\
37 \% \text {. }\end{array}$ \\
\hline $\mathrm{D}$ & $\begin{array}{l}50 \% \text { relative density reduction with no-delay in thinning. } \\
\text { Thinning was done in } 2002 \text {. Average basal area removal was } \\
53 \% \text {. }\end{array}$ \\
\hline$E$ & $\begin{array}{l}50 \% \text { relative density reduction with a } 5 \text {-year delay in thinning. } \\
\text { Thinning was done in } 2007 \text {. Average basal area removal was } \\
54 \% \text {. }\end{array}$ \\
\hline $\mathrm{F}$ & $\begin{array}{l}50 \% \text { relative density reduction with a } 10 \text {-year delay in thinning. } \\
\text { Thinning was done in } 2012 \text {. Average basal area removal was } \\
52 \% \text {. }\end{array}$ \\
\hline Control & Unthinned control plot at each study site. \\
\hline
\end{tabular}


Table 2: Stand and site information for the six commercial thinning treatments and the control in 2012. Values shown are the means \pm standard deviation across all six study sites with minimum and maximum in parentheses. TPH, QMD, BA, and Height are based on merchantable trees.

\begin{tabular}{ccccccc}
\hline Treatment & $\begin{array}{c}\text { Age } \\
\text { (yrs) }\end{array}$ & $\begin{array}{c}\text { Time since } \\
\mathbf{P C T}(\mathbf{y r s})\end{array}$ & $\begin{array}{c}\text { TPH } \\
\left.\mathbf{( \# ~ h a ~}^{-1}\right)\end{array}$ & $\begin{array}{c}\text { QMD } \\
(\mathbf{c m})\end{array}$ & $\begin{array}{c}\text { BA } \\
\left(\mathbf{m}^{2} \cdot \mathbf{h a}^{-1}\right)\end{array}$ & $\begin{array}{c}\text { Height } \\
(\mathbf{m})\end{array}$ \\
\hline A & $45 \pm 7(35 ; 54)$ & $28 \pm 1(27 ; 29)$ & $901 \pm 156(694 ; 1,141)$ & $20.9 \pm 1.3(19.1 ; 23.0)$ & $30 \pm 2(28 ; 33)$ & $14.7 \pm 1.5(12.1 ; 16.6)$ \\
B & $45 \pm 7(35 ; 54)$ & $28 \pm 1(27 ; 29)$ & $893 \pm 170(670 ; 1,141)$ & $19.5 \pm 1.3(18.4 ; 21.8)$ & $26 \pm 5(18 ; 30)$ & $15.0 \pm 0.8(14.0 ; 16.5)$ \\
C & $45 \pm 7(35 ; 54)$ & $28 \pm 1(27 ; 29)$ & $984 \pm 187(756 ; 1,290)$ & $18.3 \pm 1.7(17.2 ; 21.5)$ & $25 \pm 3(21 ; 30)$ & $15.0 \pm 1.3(12.8 ; 16.6)$ \\
D & $45 \pm 7(35 ; 54)$ & $28 \pm 1(27 ; 29)$ & $639 \pm 83(546 ; 769)$ & $22.2 \pm 1.0(20.8 ; 23.3)$ & $25 \pm 4(21 ; 32)$ & $14.4 \pm 1.3(13.2 ; 16.5)$ \\
E & $45 \pm 7(35 ; 54)$ & $28 \pm 1(27 ; 29)$ & $544 \pm 96(446 ; 670)$ & $20.6 \pm 1.7(18.6 ; 22.5)$ & $18 \pm 4(12 ; 23)$ & $14.5 \pm 0.7(13.1 ; 15.1)$ \\
F & $45 \pm 7(35 ; 54)$ & $28 \pm 1(27 ; 29)$ & $591 \pm 132(384 ; 744)$ & $19.1 \pm 1.9(16.5 ; 21.7)$ & $17 \pm 2(14 ; 20)$ & $14.8 \pm 1.4(12.9 ; 16.4)$ \\
Control & $45 \pm 7(35 ; 54)$ & $28 \pm 1(27 ; 29)$ & $1,835 \pm 200(1,612 ; 2,046)$ & $17.3 \pm 1.2(15.4 ; 18.7)$ & $43 \pm 4(38 ; 47)$ & $14.6 \pm 1.1(13.1 ; 16.5)$ \\
\hline
\end{tabular}

Notes: $\mathrm{RD}=$ relative density; $\mathrm{TPH}=$ trees per hectare; $\mathrm{BA}=$ basal area; $\mathrm{QMD}=$ quadratic mean diameter 
Table 3: Stand information for the six commercial thinning treatments at the time of treatment. Values shown are the means ıstandard deviation, and minimum and maximum in parentheses across all six study sites. TPH, BA, QMD, Piece size, Trees removed, and Vol. rem. are based on merchantable trees.

\begin{tabular}{|c|c|c|c|c|c|c|}
\hline \multirow[b]{2}{*}{ Treatment } & \multicolumn{4}{|c|}{ Pre-harvest } & \multicolumn{2}{|c|}{ Post-harvest } \\
\hline & TPH & $\begin{array}{c}\text { BA } \\
\left(m^{2} \cdot h^{-1}\right)\end{array}$ & $\begin{array}{l}\text { QMD } \\
(\mathrm{cm})\end{array}$ & $\begin{array}{c}\text { Piece size } \\
\left(\mathrm{m}^{3}\right)\end{array}$ & $\begin{array}{c}\text { BA } \\
\left(\mathrm{m}^{2} \cdot \mathrm{ha}^{-1}\right)\end{array}$ & $\begin{array}{l}\text { QMD } \\
(\mathbf{c m})\end{array}$ \\
\hline A & $1,691 \pm 252(1,331 ; 2,003)$ & $32 \pm 3(30 ; 38)$ & $15.6 \pm 1.3(14.0 ; 17.3)$ & $0.12 \pm 0.03(0.09 ; 0.17)$ & $19 \pm 1(18 ; 20)$ & $17.4 \pm 0.9(16.3 ; 18.8)$ \\
\hline B & $1,888 \pm 203(1,680 ; 2,211)$ & $36 \pm 3(32 ; 39)$ & $15.6 \pm 0.8(14.7 ; 17.0)$ & $0.13 \pm 0.02(0.11 ; 0.16)$ & $22 \pm 2(20 ; 24)$ & $16.9 \pm 0.8(16.3 ; 18.5)$ \\
\hline C & $1,853 \pm 300(1,433 ; 2,248)$ & $40 \pm 3(35 ; 44)$ & $16.8 \pm 1.6(15.5 ; 19.6)$ & $0.16 \pm 0.04(0.13 ; 0.24)$ & $25 \pm 3(21 ; 30)$ & $18.3 \pm 1.7(17.2 ; 21.5)$ \\
\hline D & $1,691 \pm 252(1,331 ; 2,003)$ & $27 \pm 3(22 ; 30)$ & $14.2 \pm 0.7(13.5 ; 15.2)$ & $0.09 \pm 0.01(0.08 ; 0.11)$ & $13 \pm 1(11 ; 14)$ & $16.0 \pm 0.9(15.0 ; 17.3)$ \\
\hline$E$ & $1,692 \pm 313(1,408 ; 2,198)$ & $31 \pm 3(26 ; 34)$ & $15.4 \pm 1.4(13.5 ; 17.0)$ & $0.12 \pm 0.03(0.08 ; 0.15)$ & $14 \pm 2(13 ; 17)$ & $17.3 \pm 1.5(15.5 ; 19.1)$ \\
\hline $\mathrm{F}$ & $1,484 \pm 397 \quad(951 ; 2,112)$ & $34 \pm 5(30 ; 42)$ & $17.5 \pm 2.0(15.5 ; 20.3)$ & $0.17 \pm 0.05(0.12 ; 0.24)$ & $17 \pm 2(14 ; 20)$ & $19.1 \pm 1.9(16.5 ; 21.7)$ \\
\hline
\end{tabular}

\begin{tabular}{|c|c|c|c|c|c|c|}
\hline Treatment & $\begin{array}{l}\text { Trees } \\
\text { removed }\end{array}$ & $\begin{array}{c}\text { BA } \\
\text { removal (\%) }\end{array}$ & $\begin{array}{l}\text { Vol. rem. } \\
\left(\mathrm{m}^{3} \cdot \mathrm{ha}^{-1}\right)\end{array}$ & $\begin{array}{l}\text { Cost }^{*} \\
\left(\$ \cdot h a^{-1}\right)\end{array}$ & $\begin{array}{c}\text { Gross Revenue* } \\
\left(\$ \cdot h a^{-1}\right)\end{array}$ & $\begin{array}{l}\text { Net Profit } \\
\left(\$ \cdot \text { ha }^{-1}\right)\end{array}$ \\
\hline A & $703 \pm 169(380 ; 823)$ & $40 \pm 5(35 ; 50)$ & $85 \pm 27(55 ; 135)$ & $941 \pm 203(580 ; 1,182)$ & $2,170 \pm 690(1,396 ; 3,424)$ & $1,229 \pm 531$ \\
\hline B & $924 \pm 98(803 ; 1,050)$ & $40 \pm 4(36 ; 46)$ & $119 \pm 19(98 ; 154)$ & $1,233 \pm 121(1,063 ; 1,365)$ & $3,029 \pm 479(2,484 ; 3,918)$ & $1,796 \pm 388$ \\
\hline C & $836 \pm 127(679 ; 963)$ & $37 \pm 3(32 ; 41)$ & $133 \pm 17(119 ; 163)$ & $1,209 \pm 87(1,070 ; 1,313)$ & $3,370 \pm 419(3,025 ; 4,155)$ & $2,161 \pm 420$ \\
\hline $\mathrm{D}$ & $1,084 \pm 171(882 ; 1,287)$ & $53 \pm 3(50 ; 57)$ & $99 \pm 14(82 ; 121)$ & $1,294 \pm 173(1,074 ; 1,480)$ & $2,526 \pm 362(2,094 ; 3,064)$ & $1,232 \pm 251$ \\
\hline E & $1,083 \pm 239(877 ; 1,507)$ & $54 \pm 4(50 ; 59)$ & $125 \pm 17(93 ; 142)$ & $1,378 \pm 206(1,233 ; 1,731)$ & $3,164 \pm 429(2,369 ; 3,621)$ & $1,786 \pm 399$ \\
\hline $\mathrm{F}$ & $865 \pm 235(531 ; 1,223)$ & $52 \pm 2(48 ; 54)$ & $140 \pm 22(112 ; 166)$ & $1,259 \pm 222(948 ; 1,631)$ & $3,569 \pm 559(2,837 ; 4,223)$ & $2,309 \pm 458$ \\
\hline
\end{tabular}

Notes: CT = commercial thinning; TPH = trees per hectare; QMD = quadratic mean diameter; $\mathrm{BA}=$ basal area; ${ }^{*}=$ at time of CT; Vol. rem. $=$ volume removed during 
Table 4: ANOVA results for fixed and random effects on the effect of treatment on maximum NPV (a), stand age at time of maximum NPV (b), and the effect of harvesting system on maximum NPV (c).

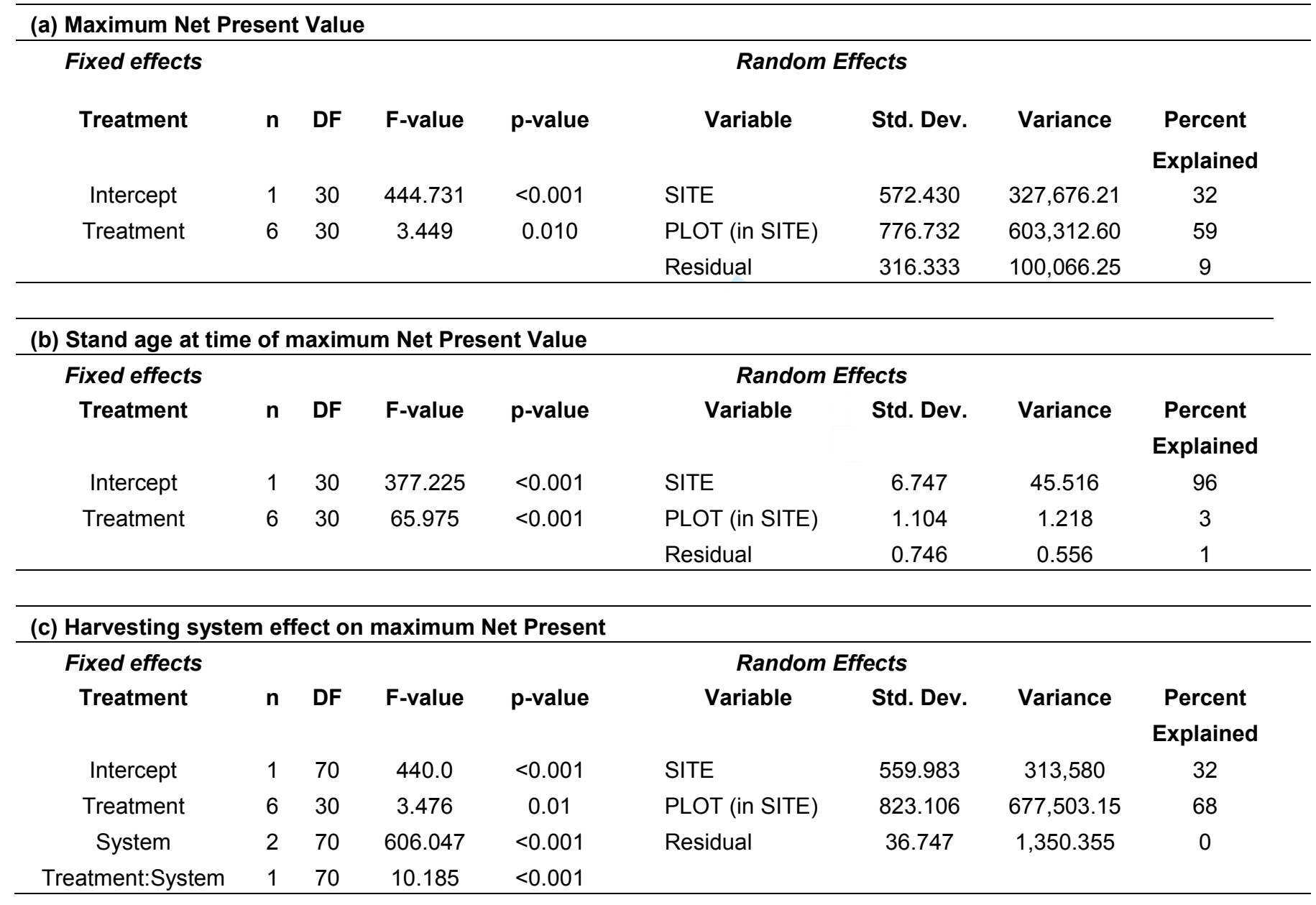


Table 5: Projected mean maximum NPV and stand age at time of maximum NPV \pm standard deviation and minimum and maximum values in parentheses for all six treatments and control at final harvest. All values are based on a CTL harvesting system.

\begin{tabular}{|c|c|c|}
\hline Treatment & $\begin{array}{c}\text { Maximum Net Present } \\
\text { Value }\end{array}$ & $\begin{array}{c}\text { Stand age at time of maximum } \\
\text { NPV }\end{array}$ \\
\hline & $\left(\$ \cdot \mathrm{ha}^{-1}\right)$ & (yrs) \\
\hline A & $6,311 \pm 988(5,244 ; 7,838)^{a}$ & $49 \pm 6(40 ; 57)^{a}$ \\
\hline $\mathrm{B}$ & $6,346 \pm 1,206(4,607 ; 8,172)^{a}$ & $54 \pm 7(45 ; 63)^{b}$ \\
\hline $\mathrm{C}$ & $6,081 \pm 1,027(5,075 ; 7,991)^{a}$ & $59 \pm 7(50 ; 67)^{c}$ \\
\hline $\mathrm{D}$ & $5,731 \pm 856(4,994 ; 7,154)^{a}$ & $50 \pm 7(40 ; 58)^{a}$ \\
\hline$E$ & $5,007 \pm 959(3,654 ; 6,046)^{a}$ & $54 \pm 7(44 ; 63)^{b}$ \\
\hline $\mathrm{F}$ & $4,956 \pm 651(4,254 ; 5,910)^{a}$ & $60 \pm 7(49 ; 68)^{c}$ \\
\hline Control & $5,002 \pm 1,287(3,611 ; 6,492)^{a}$ & $49 \pm 7(39 ; 59)^{a}$ \\
\hline
\end{tabular}

Note: different letters following maximum net present value and rotation length indicate statistical differences among treatments. 


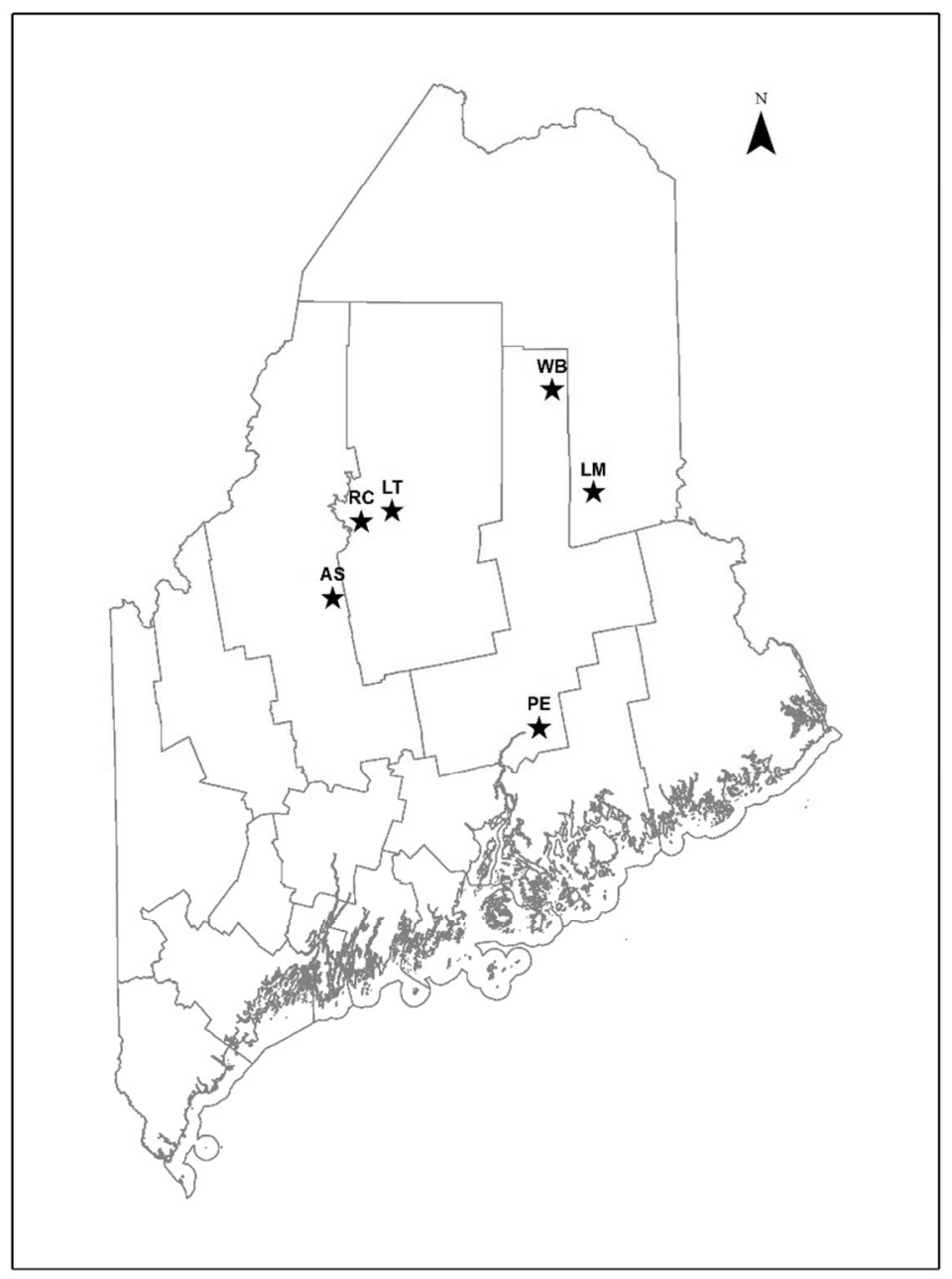

Figure 1: Study site location across the state of Maine with county boundaries. Note: AS = Alder Stream site, LT = Lazy Tom study site, LM = Lake Macwahoc study site, RC = Ronco Cove study site, $\mathrm{PE}=$ Penobscot Experimental Forest study site, $\mathrm{WB}=$ Weeks Brook study site 

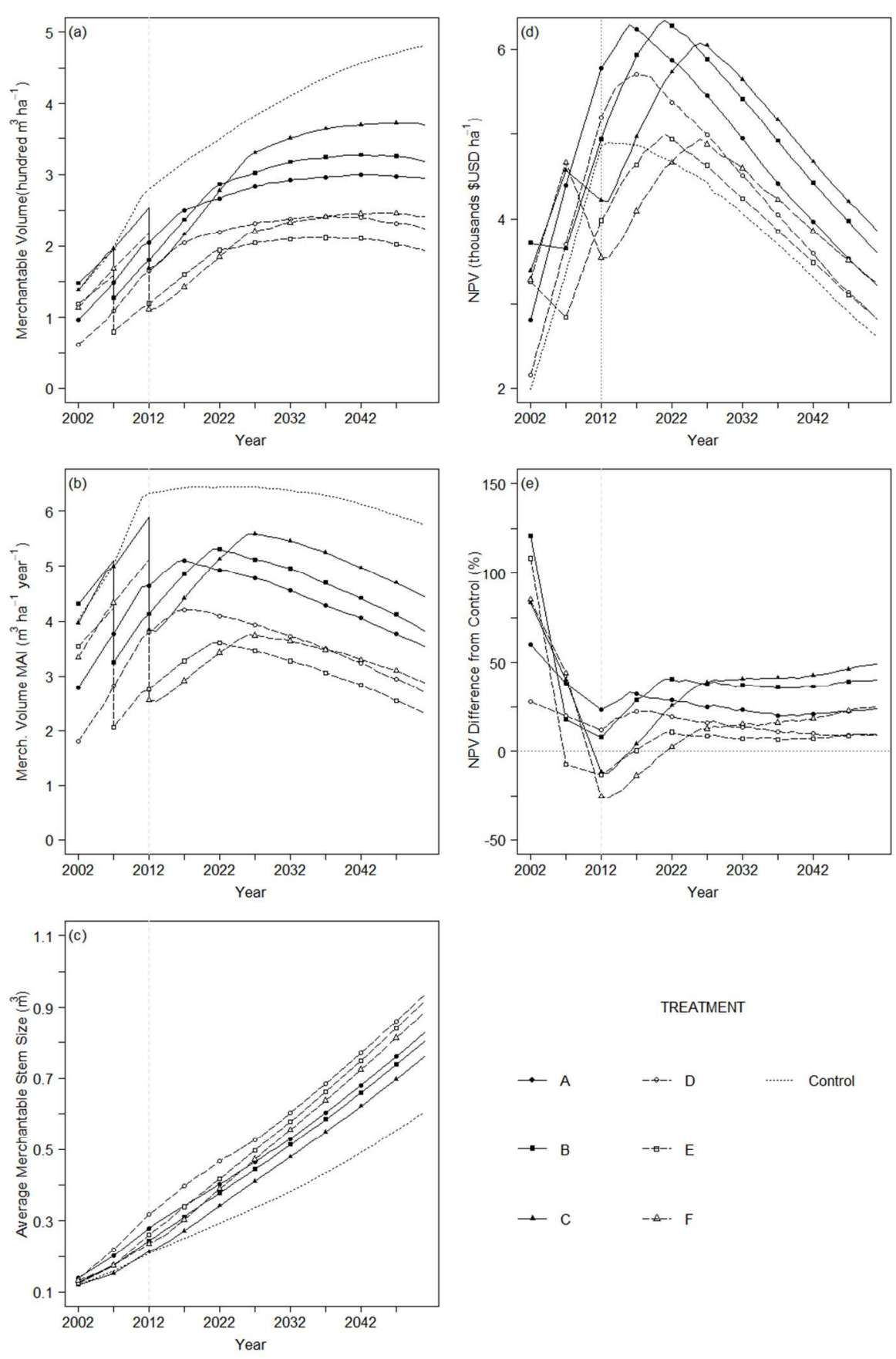

Figure 2: Response of merchantable volume (a), gross merchantable volume MAI (b), average merchantable stem size (c), net present value (d), and net present value difference from the control following a CT treatment (e). Data after 2012 is projected, whereas data until 2012 was measured. Data shown represents the average for each treatment across all six study sites. 


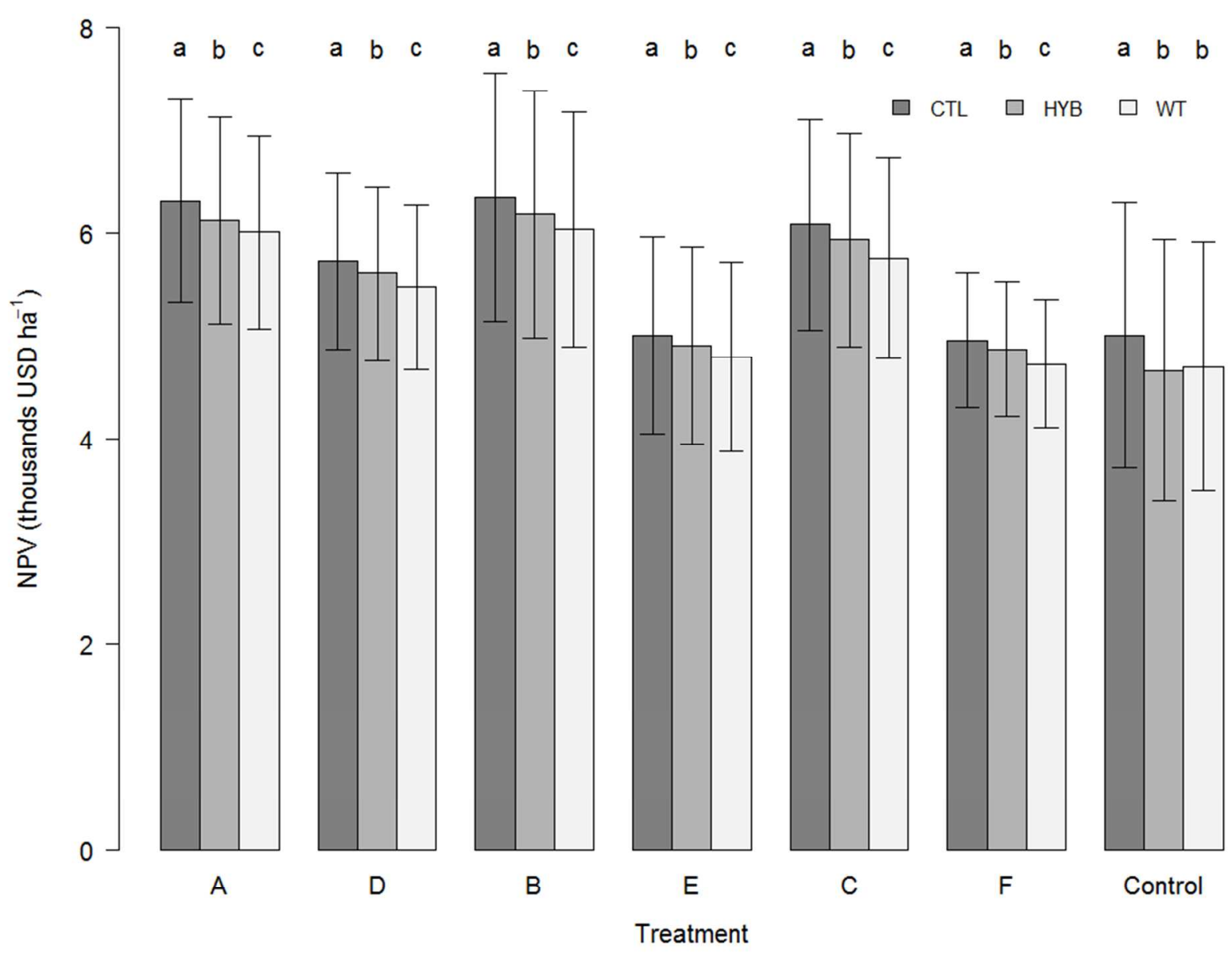

Figure 3: Maximum net present value (NPV) and on standard error bars for six treatments and one control plot across six study sites, with three different harvesting systems. The letters above the individual bars show the statistical significance between systems within each treatment but do not compare across treatments. Products harvested by all systems included roundwood only and did not include biomass chips. 


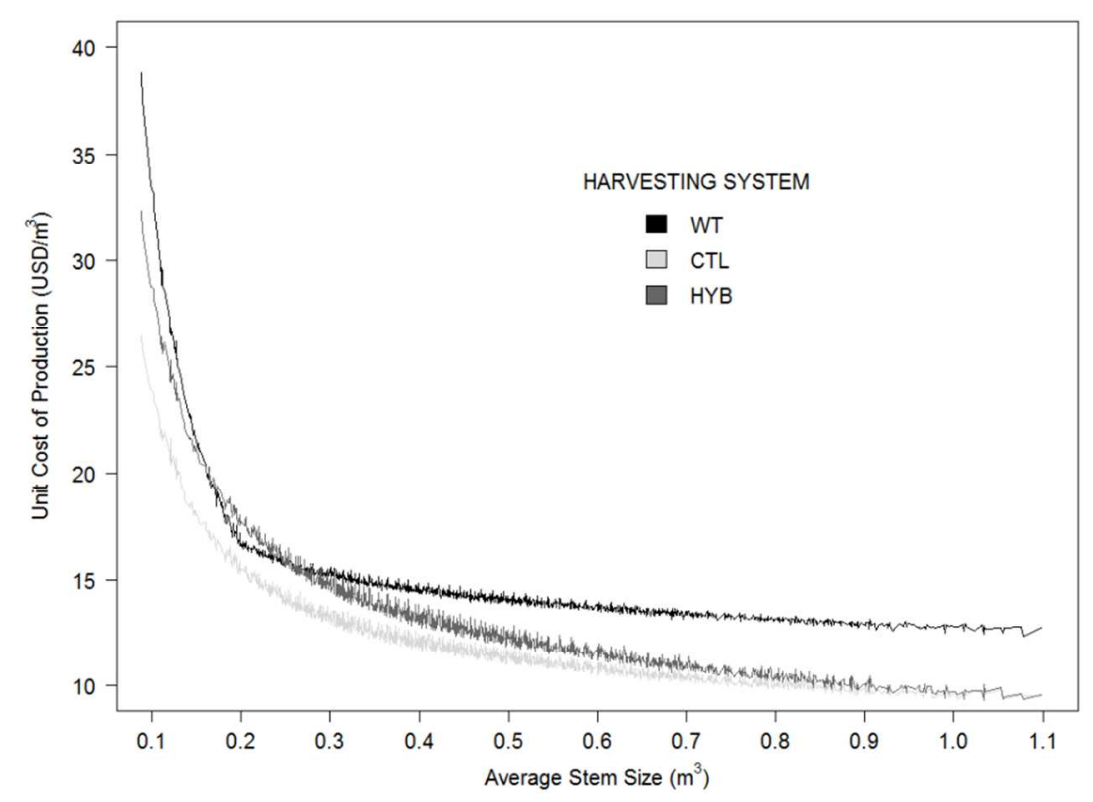

Figure 4: Unit cost of production of three harvesting systems from stump to landing. 

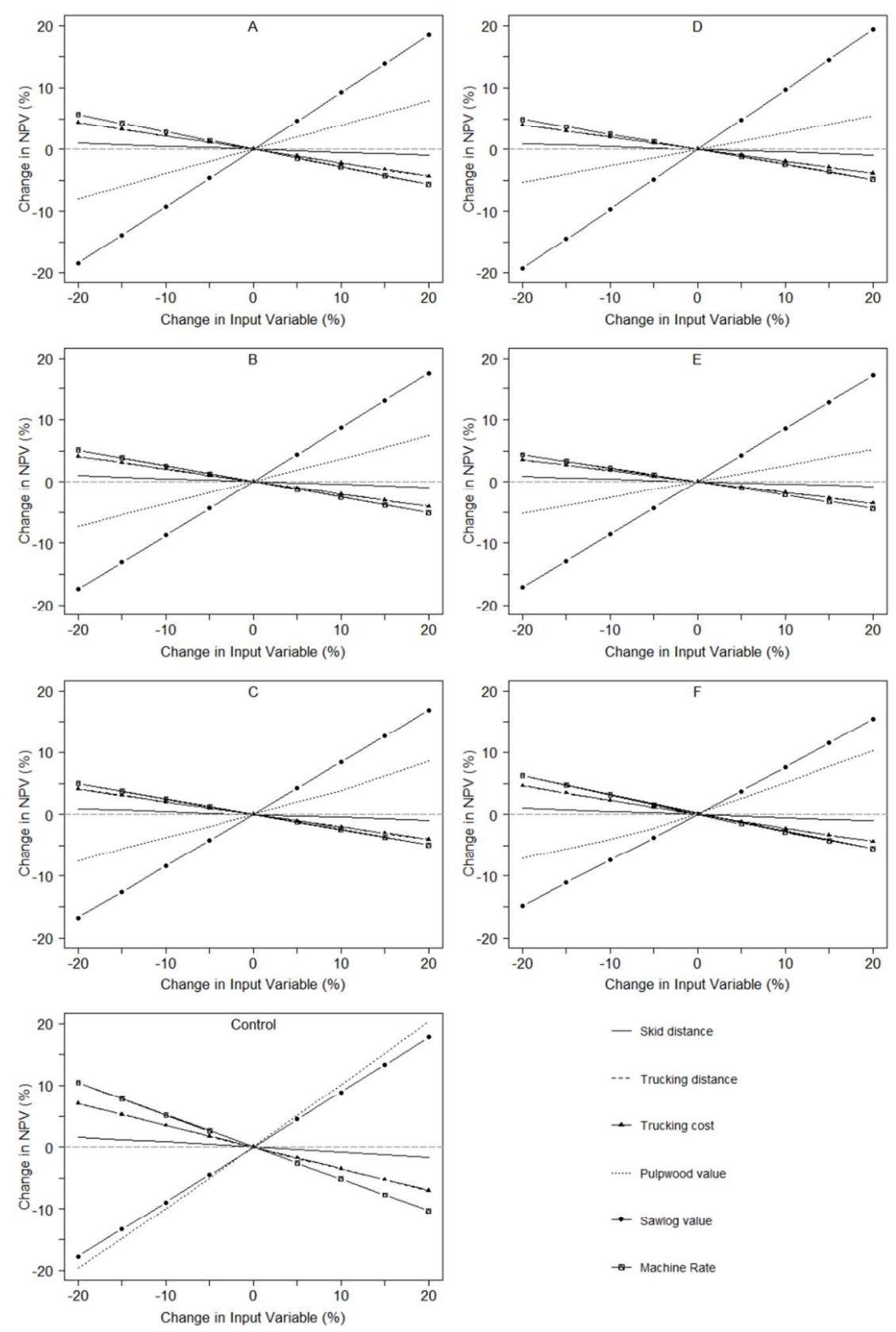

- Skid distance

--- Trucking distance

- Trucking cost

...... Pulpwood value

$\rightarrow$ Sawog value

* Machine Rate

Figure 5: Sensitivity of maximum NPV to changes in input variables based on a light thinning with no delay. A change of $0 \%$ in input variables represents the baseline conditions as outlined in this manuscript. The curves for a change in trucking distance and trucking costs overlay each other and are not distinct from each other. Letters in the top center of each figure represent the treatment. 